\title{
Analysis of the Influence of Institutional Dynamics on Juvenile Criminality in Nakuru Sub-County, Kenya
}

\author{
Justus O. Kiche Dr. Solomon P. K. Muhindi \\ Institute of Security Studies, Mount Kenya University, P.O.BOX 342-01000, Thika \\ Dr. Ruth W. Thinguri \\ School of Education, Mount Kenya University, P.O.BOX 342-01000, Thika
}

\begin{abstract}
The present study was prompted by the observation that there was very high prevalence of juvenile criminality in Kenya. This study focused on analyzing the influence of institutional dynamics on juvenile criminality in Nakuru sub-county, Kenya. The target population for the study was 144 that included 73 police officers from Bondeni police station, 35 juveniles drawn from children remand home, 35 parents/guardians of the said juveniles, and 1 chief from Bondeni location. The researcher selected a sample size of 102 respondents composed of 62 police officers, 32 juveniles, 7 parents/guardians, and 1 chief. The researcher used a questionnaire and an interview schedule to collect views. The validity of this study was achieved through a thorough consultation with the supervisors and other specialist. Reliability was used to focus on the degree to which empirical indicators are stable and consistent. A Cronbach's coefficient alpha was used to measure the reliability of the research instruments. An alpha coefficient value of 0.6 suggested the instrument is reliable. The study adopted the mixed research methodology and the concurrent triangulation design. Quantitative data was analyzed descriptively and inferentially while qualitative data was analyzed thematically. The study found out that there was an important positive association between all the measures of institutional dynamics and juvenile criminality in Nakuru subcounty. The study concluded that there was an influence of institutional dynamics and juvenile criminality in Nakuru sub-county, Kenya. The study recommends that the government should make efforts in making families functional in order to reduce juvenile criminality. There is therefore need for juvenile department to improve on their policies and expected performance in regard to juvenile criminality.
\end{abstract}

Keywords: Kenya, Nakuru, Biological dynamics, crime, doliincapax, economic dynamics, government dynamics, juvenile, social dynamics, urban.

DOI: $10.7176 / \mathrm{JLPG} / 97-07$

Publication date:May $31^{\text {st }} 2020$

\subsection{Background to the Study}

Juvenile criminality involves participating in a criminal behavior by a juvenile (Siegel and Welsh, 2011). Juvenile criminality is determined by multiple biological, social, economic and government dynamics which are typically interrelated in complex ways (Lipsey \& Derzon, 1999; Loeber \& Farrington, 1998). Globally, children aged 1014 years were incapable of having knowledge of committing crime in any court hearing (to be doliincapax)- unable to commit crime (Elizabeth \& Laurence, 2008). For instance, in England, it was the prosecution to prove beyond reasonable doubt that a juvenile had committed an offence (Newburn, 2002). In our country Kenya, the study that was done in Kamiti Youth Corrective Training Centre (KYTC) showed that the age, gender, poor parenting skills, lack of jobs, positioning of birth of children, peer pressure, poverty, lack of government policy have been some of the reasons why juvenile criminality is rampant. (Omboto, 2013). In Kenya, there are eleven Juvenile Remand Homes, all of them under the Department of Children's Services. Nakuru County is one of the counties in Kenya that is exposed to the pressures of crime. Several clashes in the county led by the juveniles indicate how they involve themselves into criminal activities (Falcetto, 2012). According to regional crime trend analysis in the police annual crime report (2014), the regions which recorded increases in crime were Nyanza 22\%, North Eastern 18\%, Central 9\% and Rift Valley 3\%. According to Omboto (2013) the minors are not able to distinguish which factors will perpetuate their indulgence into criminal activities. They therefore get involved in criminal activities without their knowledge. According to Mooney and Young (2006), studies need to be carried out to identify the context and specific factors that promote juvenile involvement in crime. The parents shift their blame to the juveniles while the juveniles shift their blame to the errant government policies. In effort to correct the existing void, the study therefore sought to analyze the influence of institutional dynamics on juvenile criminality in Nakuru sub-county, Kenya.

\subsection{Statement of the Problem}

The issue of juveniles engaging in criminality is a global agenda. Juvenile criminality is considered as one of the problems and concerns of different countries. This phenomenon has a growing trend in our country as one of the youngest countries in the world. The various Crime prevention programmes have no enough resources to deal with 
such a scourge. Juvenile criminality has been proved by previous records showing those who are killed or those caught committing acts like mugging and murder including records of crime during 2007/2008 general election. In Kenya there had been high rate of juveniles engaged in criminality indicated by the high number of them arrested or sentenced due to criminal acts. The tough laws have failed to reduce crime effectively. There was no much that had been written down on institutional dynamics that cause juvenile criminality. Due to that, it had made it hard for police officers and other stakeholders that deal with juvenile criminality in coming up with appropriate strategies on dealing with such cases of criminality among the juveniles, hence, the need for this study. Therefore, the study was important as it assessed the influence of institutional dynamics on juvenile criminality in Nakuru sub-county, Kenya for the purpose of recommending appropriate actions to address the situation. Nakuru County is one of the urban areas in Kenya which was highly populated and was a metropolitan area with mixed ethnic backgrounds. Biological dynamics included genetic heredity, gender, positioning of birth of children. Social dynamics were matters that affected lifestyle, such as religion; family or wealth, drug abuse, rural-urban migration, reference group, role and status, beliefs. Economic dynamics included costs such as wages, interest rates, governmental activity, laws, policies, tax rates, unemployment level, poverty, inflation rate, labor costs. The study therefore aimed to fill the identified gaps by analyzing if there was an influence of institutional dynamics and juvenile criminality in Nakuru sub-County, Kenya.

\subsection{Purpose of the Study}

The main purpose of the study was to analyze the influence of institutional dynamics on juvenile criminality in Nakuru sub-county, Kenya.

\subsection{Objective of the Study}

The following objectives guided the study:

- To assess the influence of biological dynamics on juvenile criminality in Nakuru sub-county, Kenya;

- To establish the influence of social dynamics on juvenile criminality in Nakuru sub-county, Kenya;

- To examine the influence of economic dynamics on juvenile criminality in Nakuru sub-county, Kenya;

- To ascertain the influence of government dynamics on juvenile criminality in Nakuru sub-county, Kenya.

\subsection{Research Question}

The research sought to answer four questions;

- To what extent do biological dynamics influence juvenile criminality in Nakuru sub-county, Kenya?

- What is the influence of social dynamics on juvenile criminality in Nakuru sub-county, Kenya?

- How do economic dynamics influence juvenile criminality in Nakuru sub-county, Kenya?

- How do government dynamics influence juvenile criminality in Nakuru sub-county, Kenya?

\subsection{Justification of the Study}

It was expected that the findings of this study would add knowledge and literature provided for by other authors and academicians. The study findings would also benefit the stakeholders in the field of education, especially in policy and leadership in Nakuru sub-county. Secondly, the study analyzed whether institutional dynamics have influence on juvenile criminality in Nakuru sub-county.

\subsection{Significance of the Study}

First, the research may have helped approve a plan to train parents and teachers on how to detect juvenile criminality. This prevented maladaptive behavior and activities that led them to being criminals. Research may have been useful to the security firms in understanding the nature of crimes committed by juveniles. Information from the study may have helped the government in developing more effective strategies in dealing with criminal activities among the juveniles. The study may have helped the general public in understanding the increase in rate of criminal activities by the juveniles.

\subsection{Literature Review}

\subsection{Influence of Biological Dynamics on Juvenile Criminality}

The issue of biological concerns on criminality is based on abnormal functioning of the brain. It has also been linked to such anomalies as aphasia, dyslexia and hyperactivity, which makes one to turn to criminal acts. There is also a relationship between criminality and brain disorder. According to various studies on criminal activity in relation to age, have steadily shown that the rate of indulging in crime start to go up at pre-adolescence or at the early stages of adolescence and progress to prime levels at late adolescence and diminish towards early adulthood (Farrington \& National Research council 1986). In America some law breaking exposure at certain period during adolescence is almost the same in children the whole of America, however this behavior is insignificant and impermanent. Even though the real age of the beginning, peak and age of restraining differ based on the offense, 
the sequence has remained steady over time, in varying nations and for the formal and for self- reported data. For instance, in a longitudinal study by (Farrington 1986), where a number of boys were sampled in London (the Cambridge Longitudinal Think about), discovered that an there was eight times increment in the number of distinctive boys indicted of reprobate behavior from age 10 to age 17, subsequently the number reduced to a quarter of the most extreme level by age 24. Also similar numbers of self-reported offenses within the same test more over went up to highest levels between ages 15 and 18, and at that point dropped strongly by age 24 .

Females of different ages were found to indulge themselves into various serious crimes.

Studies recently done have also shown that there are those juveniles who begin to offend very early in life, others in the middle age while others at later age (e.g., Moffitt, 1993). According to research by Trembly and Nagin 1999 discovered, that there was no connection between late development and physical violence.

Those who continue engaging in criminal offences through to their adulthood contrast from those who cease in a number of ways because of their attachment to schools and military service (Laub 1996). It may also be based on sex, age they started committing crimes, imprisonment and adult social bonding like marriages, stability of work and the quality of marriage (Farrington and West, 1995; Quinton et al., 1993; Quinton and Rutter, 1988; Sampson and Laub, 1990). Sampson \&Laub in 1993 discovered that conjugal connection and work steadiness essentially diminished deviant behavior in adulthood. Farrington and West (1995) found that wrongdoers and nonoffenders were similarly likely to be married, but those who got married and lived with their companion diminished their deviant behavior more than those who remained single or who did not live with their companion. They too found that deviant behavior expanded after division from a life partner. Essentially, Horney et al. (1995) found that married male wrong doers diminished their deviant behavior when living with their companions and continued with their bad behavior when not living with their spouses.

\subsection{Influence of Social Dynamics on Juvenile Criminality}

There are scholars who suggest that crime is as a result of social product or dynamics such as broken families, peer pressure, urbanization, and rapid social change (Regoli \& Hewitt, 1994). Steinberg (1987) stated that "the influence of peers and their acceptance of juvenile criminality are significant, and this relationship is magnified when a juvenile has little interaction with his parents". McCord and colleagues (2001:80), stated that dynamics such as peer delinquent behavior, peer approval of delinquent behavior, attachment to peers, time spent with peers, and peer pressure for deviance have all been associated with juvenile criminality. Mental hypotheses accept that antisocial behavior is as a result of modeling, learning from the environment, childhood clashes and cognitive components. Ponder discoveries and writing checked on by Besemer (2007) appear that sedate utilize; tutoring and scholarly execution; family variables, particularly components related with child rearing behavior and styles are related to misconduct. Loeber and Stouthamer-Loeber (1986) conducted ameta-analysis of concurrent and longitudinal considers on the connection of family variables (counting parental inclusion with children, parental supervision, parental teach, parental dismissal of their children, child's dismissal of the parent, parental culpability and animosity, conjugal relations, and parental nonappearance) to adolescent misconduct to conduct issues and concluded that a few components were more effective indicators of adolescent conduct issues and misconduct than others.

According to Lochner and Moretti's (2004), it is important to understand the link that exist between the education and the causative agents and the direction of crime. In their study Lochner and Moretti identified the influence that education had on engaging in criminal activities by applying law changes in compulsory school leaving age (SLA) for a certain period of time to monitor the relationship between education and crime. Looking at individual-level information on detainment from the 2001 Census and related level board information on offenders rate from the Domestic Office offenders List Information (OID) within the period from 1984 to 2002 , the study found out that schooling essentially diminishes detainment rates and property wrongdoing.

According to Social learning theory aggressive behavior is acquired by children when they see the parents exhibiting the same behavior and kids look at it as the right and acceptable way of attaining goals (Wright\& Wright, 1994). Poor monitoring and close monitoring, erratic chastisement and corporeal castigation have been associated with delinquent and violent behavior at later stages of life (Farrington, 2002). Merton's anomie theory provides that, every society has goals and means to achieve those goals. Where goals are not reached its likely to result into stress and anomie, to this extent some may try other methods such as crime in reaching unachievable goals (Hirschi, 1969). Social disorganization is another theory in which the Chicago School of Sociology developed in 1900 (Jensen, 2003). The theory entails on the absence of organization among social institutions such as family, school, and church can also be a risk factor. It is the breakdown of relationships in institutions which traditionally encouraged cooperation among the people and the society at large. Apart from explaining the absence of organization in social institutions the theory also explains the occurrence of crimes due to the fact that the social disintegration means there will be absence of norms and rules may be broken. In relation to the rate of crime Faris (1955) extends the disorganization concept entailing that a crime is reflection of degree of disorganization of control mechanism in a society. 


\subsection{Influence of Economic Dynamics on Juvenile Criminality}

Families' economic status is determined by income, livelihood, and education levels, the number of children in a family and tangible assets available home (Githua, 2002). Amato and Keith (1991) and Apel and Kaukinen (2008) found that parental economic hardship contributes to economic pressure which in turn predicted parental irritability and emotional distress. Lundaman, (2001) noted that deteriorated poverty ridden areas of cities tend to produce social disorganization which in turn leads to criminality. Prior and Paris (2005) indicated that most of the juveniles are involved in criminality due to poverty. This is also echoed by Shaw and McKay (1969) in their volume Juvenile Delinquency and Urban Areas where they stated that juvenile criminality areas are highly correlated with poverty and low incomes. Criminal behavior and crime is often associated with poor economic standards (Lotz, Poole \&Regoli, 1985). More than $60 \%$ percent of Kenyans live below poverty lines, earning less a dollar per day (the Kenya Children's Parliament, 2004). This form of poverty exposes young children in these families to operate in conditions that will encourage the juvenile behavior. Small families have the capacity to effectively take charge of their affairs and effectively provide for children's basic needs. Crime is likely to take place in large family units because most of them are found in the lower social economic strata (Thornton \& Voigt, 1992). Study findings shows that kids from big families are the most affected by delinquent acts as compared to kids from small families (Wasserman \&Seracini, 2001; West \& Farrington, 1973).

Bandura \& Walters (1959) assert that in the approach to the problem of criminal behaviour, sociologists have focused more on the significance of social environment as the contributing factor. The authors hypothesize that the high delinquency areas are characterized by a state of social disorganization, poverty, economic reliance and the missing reliable locality values of behaviour. Poverty and poor living conditions led to frustration and discontent, which fosters a hostile attitude to society. These conditions led to the formation of gangs, here the members' behaviour and values run contrary to those of the larger community.

According to Shaw (1966) the delinquents come from families which are usually poverty stricken and which have only one parent. When there are no effective deterring morals in a family or a community, the growth of and development of juveniles and their peers outside homes are unguided. Several parents searching for limited or no jobs in urban set up's become poor, with their kids fate ending up residing in over-populated un planned settlements commonly referred to as slums such as Bondeni in Nakuru sub-county. In search of a better environment, children from the slums loiter into the city centre where they can easily drift into delinquency. (Wambayi, 1984).Most juvenile delinquents come from very poor single parents, usually female. Most of their parents are unemployed or engage in unstable, unreliable and illegal income-earning activities, like prostitution, unlicensed hawking, or brewing and selling chan'gaa. Because these activities are illegal, mothers are constantly harassed by the authorities, and end up frequently losing their wares and earnings. Occasionally they end up in prison, thereby leaving their children to fend for themselves (GOK/UNICEF, 1992).

Poverty levels soars the world day after day bringing different problems in societies one of them being high number of homeless children in developing countries (UN-Habitat, 2004). Moreover, poverty being an economic problem parents are unable to meet family needs such as education, healthy and food. Failure to reach children's material needs, children engage in all sorts of activities most of which are illegal (Bosiakoh and Andoh, 2010). Poverty brings about vulnerability which means defenselessness, insecurity and exposure to many risks, shock and stress. It is worth noting that, analysis on social ecology of poverty and unemployment are very important in understanding the precise nature and extent of juvenile offending in any locale (Weijters, 2008). In addition, poor people always live in areas with low quality social services like poor houses, poor education facilities resulting into poor education, and they experience declining quality in their healthy and social welfare at large. In such vulnerable lifestyle, unemployment is inevitable to youth leading to a problem cycle. The situation is so frustrating hence many young people substitute in criminal activities to achieve their goals to live a better life.

However, low income has not been the only cause to juvenile crimes since high income also contributes in pushing up the crime rate in different communities. Types of crimes such as violent crimes, crimes done under the influence of substance use and crimes of using illegal drugs such as marijuana are also committed by juvenile from higher income families. Enough income to their pockets, freedom on how to spend the money has provided a loop holes to juvenile purchasing alcohol and drugs. In addition, juvenile from such class are able to purchase tools like guns enabling them to commit other offences (Anderson and Hughes, 2009).

\subsection{Influence of Government Dynamics on Juvenile Criminality}

According to Vanderschueren (2000) the government is taking the following measures to prevent young offenders from re-offending:

Each youngster is extraordinary and merits bolster that is particularly custom fitted to them. For instance, a forceful individual can be requested to go to a course to figure out how to adapt to and control hostility. The Offending Behavior Programs Accreditation Committee surveys the courses to decide if they have really had the coveted impact. At the point when a youngster is discharged from youthful guilty parties' foundation, he or she needs to reintegrate into society by going to class or college, or finding a vocation. The preparation and training 
programs gave toward the finish of the custodial period are proposed to enable them to get ready for this. Youthful wrongdoers' institutions, the Child Protection Board, the Youth Probation Service and sub-regions cooperate in system and process-related consultative bodies. They mastermind protect, wage, training as well as work for youthful guilty parties upon discharge.

According to Vanderschueren (2000) early intercession assumes an essential part in shielding minors from setting out on an existence of wrongdoing. Quick and steady discipline for offenses can help lessen the rate of wrongdoing. In the wake of serving their sentence, youthful wrongdoers get bolster went for avoiding re-affronting. According to Vanderschueren (2000) at the point when a minor is striven for an offense, the guardians or watchmen are required to go to the procedures with the goal that the judge can get a feeling of the family circumstance and the minor concerned. In the event that the guardians neglect to go to a hearing, the court can issue a warrant to anchor their participation in court. In such cases, the police get the guardians at home and escort them to court. Guardians are likewise required before the trial. The police frequently converse with the guardians and the Child Protection Board likewise sets up contact with them. The Youth Probation Service gets in touch with them after the pre-preliminary detainment arrange is lifted.

According to Vanderschueren (2000) young lady scouts, boy troopers, church youth gatherings, and volunteer gatherings all include youth inside a network. Contribution in local gatherings furnish youth with a chance to connect in a sheltered social condition. Juvenile and youth crime being a worldwide problem and it being one of the major challenges to sustainable cities variety of measures have been suggested and taken into an account. Just as there is no single cause to crime and violence, there is no single solution to the problem. According to Vanderschueren (2000) in UNCHS document the fight against crime is based on three principles which are law enforcement, solidarity and crime prevention. In law enforcement suppression of crime by the government organs responsible for maintenance of law and order, law enforcement and decree of other authorities is important.

\subsection{Research Methodology and Design}

In achieving the objective of the study, the researcher adopted the mixed approach of research (Tashakkori \& Teddlie, 2003). Mixed method approach is an aspect of both quantitative and qualitative procedures (Creswell, 2003). This method emanates from the conviction that neither quantitative nor qualitative approach is selfsufficient. Concurrent-triangulation design was applied, it is a mixed method strategy whereby the researcher converged quantitative and qualitative quantitative and qualitative data in order to provide a comprehensive analysis of the research problem (Creswell, 2003). The design explored in-depth and holistic understanding of the phenomenon. Both quantitative and qualitative approaches were used in data collection by use of questionnaires, and interview schedule. The two approaches were used so that the overall strength of the study is greater than either qualitative or quantitative research as stated by Creswell \& Clark (2007). Quantitative data was analyzed descriptively and inferentially. Descriptive statistics was analyzed using frequencies and percentages and reports presented using tables. Inferential statistics was analyzed using Pearson Correlation Coefficient and presented in tables. Qualitative data was analyzed thematically and presented in narrative form and quotations.

\subsection{Research Findings and Discussions}

\subsection{Descriptive Data Analysis}

Table 1: Extent to which biological dynamics have influenced juvenile criminality (Police officers)

\begin{tabular}{|l|c|c|c|}
\hline Statement & N & Mean & $\begin{array}{c}\text { Std. } \\
\text { Dev. }\end{array}$ \\
\hline Genetic heredity has an influence on the type of crime committed by a juvenile & 62 & 3.24 & .894 \\
\hline Positioning of birth of a child proves the age of onset of criminality & 62 & 3.44 & .967 \\
\hline $\begin{array}{l}\text { Gender indicates the frequency of juvenile criminality in that there are increasing } \\
\text { rate among male and female juvenile crimes }\end{array}$ & 62 & 3.38 & .875 \\
\hline $\begin{array}{l}\text { Family experience and exposure whereby other family members had been involved } \\
\text { in criminality can make the others also to engage in juvenile criminality }\end{array}$ & 62 & 3.67 & 1.046 \\
\hline Type of family and parenthood affects child's behavior in relation to criminality & 62 & 3.24 & .894 \\
\hline $\begin{array}{l}\text { Family education in that lack of knowledge influences juveniles to crime } \\
\text { commission }\end{array}$ & 62 & 3.44 & .967 \\
\hline Dysfunctional family can make juveniles to engage themselves to crime & 62 & 3.14 & .882 \\
\hline
\end{tabular}

Means: $0-1.5=\mathbf{S D}, 1.6-3.1=\mathbf{D}, 3.2-4.7=\mathbf{A}$, Above $4.7=\mathbf{S A}$

Key: $\boldsymbol{S D}=$ Strongly Disagree, $\boldsymbol{D}=$ Disagree, $\boldsymbol{N}=$ Neutral, $\boldsymbol{A}=$ Agree, $\boldsymbol{S} \boldsymbol{A}=$ Strongly Agree

Source: Field Data, (2019)

The study results revealed that the statement family experience and exposure whereby other family members had been involved in criminality can make the others also to engage in juvenile criminality. It had the highest mean score of 3.670 followed by the statement that positioning of birth of a child proves the age of onset of criminality with a mean score of 3.440. However, the statement that genetic heredity has an influence on the type of crime 
committed by a juvenile had a mean of 3.240) and the statement that dysfunctional family can make juveniles to engage themselves to crime had the lowest mean of 3.140. The study results showed that the overall mean score of influence of biological dynamics on juvenile criminality in Nakuru sub-county was 3.36. This meant that respondents agreed with the statements measuring the first objective. This had the implication that biological dynamics had an influence on juvenile criminality in Nakuru sub-county. The findings concurred with observations in the literature, there is general agreement that behavior, including antisocial and delinquent behavior, is the result of a complex interplay of individual biological and genetic factors and environmental factors, starting during fetal development and continuing throughout life (Bock and Goode, 1996). Clearly, genes affect biological development, but there is no biological development without environmental input hence criminality.

Table 2: Extent to which social dynamics have influenced juvenile criminality (Police officers)

\begin{tabular}{|c|c|c|c|}
\hline Statement & $\mathbf{N}$ & Mean & $\begin{array}{l}\text { Std. } \\
\text { Dev. }\end{array}$ \\
\hline Peer influence motivates young people to criminality. & 62 & 2.56 & .575 \\
\hline $\begin{array}{l}\text { Many communities and parents lack awareness on the importance of educating } \\
\text { young ones on the consequences of drug abuse and criminality }\end{array}$ & 62 & 2.10 & .631 \\
\hline High rates of urban migration is an influential attribute to juvenile criminality & 62 & 2.16 & .628 \\
\hline $\begin{array}{l}\text { Parents fail to support the juveniles on what programs they are supposed to watch } \\
\text { on media }\end{array}$ & 62 & 2.11 & .784 \\
\hline $\begin{array}{l}\text { Absence of a smooth transition in the family structure makes juveniles commit } \\
\text { crime leading to incarceration }\end{array}$ & 62 & 2.36 & .680 \\
\hline $\begin{array}{l}\text { Lack of supervision and school drop-out has also influenced juvenile criminality } \\
\text { Overall Mean score }\end{array}$ & 62 & $\begin{array}{l}2.38 \\
2.28\end{array}$ & .565 \\
\hline
\end{tabular}

Means: $0-1.5=\mathbf{S D}, 1.6-3.1=\mathbf{D}, 3.2-4.7=\mathbf{A}$, Above $4.7=\mathbf{S A}$

Key: $\boldsymbol{S D}=$ Strongly Disagree, $\boldsymbol{D}=$ Disagree, $\boldsymbol{N}=$ Neutral, $\boldsymbol{A}=$ Agree, $\boldsymbol{S} \boldsymbol{A}=$ Strongly Agree

Source: Field Data, (2019)

The study results showed that the overall mean score of influence of social dynamics on juvenile criminality in Nakuru sub-county was 2.28 . The study findings in relation to peer influence in motivating the juveniles to criminality indicated that there was a mean of 2.56 and SD of 0.575 . Drug abuse on the other hand could not make juveniles commit crime when parents lack awareness on the importance of educating their juveniles on the consequences of drug abuse. This was revealed by a mean of 2.10 and SD of 0.631 . On high rates of urban migration, a mean of 2.16 and SD of 0.628 were obtained. On the issue of parents failing to support the juveniles on what programs they are supposed to watch on media, a mean of 2.11 and SD of 0.784 were obtained. In regard to the absence of a smooth transition in the family structure that can make juveniles commit crime hence incarceration, a mean of 2.36 and SD of 0.680 were obtained. In regard to lack of close supervision and school drop-out and how it can influence juvenile to engage themselves in crime, a mean of 2.38 and SD of 0.565 were obtained. The above findings concurred with and relate to various observations in the literature like those of Steinberg, (1987) who noted that at a given percentage the influence of peers and their acceptance of criminal behavior are significant and the relationship is magnified when juveniles have no time with their parents.

Table 3: Extent to which economic dynamics have influenced juvenile criminality (Police officers)

\begin{tabular}{|c|c|c|c|}
\hline Statement & $\mathbf{N}$ & Mean & $\begin{array}{l}\text { Std. } \\
\text { Dev. }\end{array}$ \\
\hline Poverty necessitates juveniles to criminality. & 62 & 2.38 & .756 \\
\hline Income inequality and distribution to children can make them commit crime & 62 & 2.83 & .842 \\
\hline Unemployment by parents is a major factor of juveniles to engage in crime & 62 & 2.67 & .968 \\
\hline Child labor can make a juvenile do criminal act & 62 & 2.48 & .894 \\
\hline $\begin{array}{l}\text { Juveniles receive enough training, vocational skills and counseling for positive } \\
\text { behavior change }\end{array}$ & 62 & 2.69 & .892 \\
\hline Overall Mean score & & \multicolumn{2}{|c|}{2.61} \\
\hline
\end{tabular}

Means: $0-1.5=\mathbf{S D}, 1.6-3.1=\mathbf{D}, 3.2-4.7=\mathbf{A}$, Above $4.7=\mathbf{S A}$

Key: $\boldsymbol{S D}=$ Strongly Disagree, $\boldsymbol{D}=$ Disagree, $\boldsymbol{N}=$ Neutral, $\boldsymbol{A}=$ Agree, $\boldsymbol{S} \boldsymbol{A}=$ Strongly Agree

Source: Field Data, (2019)

The study results showed that the overall mean score of influence of economic dynamics on juvenile criminality in Nakuru sub-county was 3.36. On how poverty necessitated juveniles to criminality, it was supported by a mean of 2.56 with a SD of 0.575 . In regard to income inequality and its distribution to children, a mean of 2.10 and a SD of 0.631 were obtained. Based on the argument of why unemployment is a major dynamic of juveniles to engage in crime, a mean of 2.16 and a SD of 0.628 were obtained. On the issue of child labor and how it can make a juvenile commit crime, a mean of 2.11 and a SD of 0.784 were obtained. To a greater extent, juveniles receive enough training, vocational skills and counseling for positive behavior change. This was indicated by a 
mean of 2.36 and a SD of 0.680. These findings also concur with those of Amato and Keith (1991) and Apel and Kaukinen (2008) who found that parental economic hardship contribute to economic pressure. According to Kamuzora and Mkanta (2000), big family size does not mean poverty. It is the real picture of patriarchal power relationship within families where juveniles provide labor (Kamuzora and Mkanta, 2000).

Table 4: Extent to which government dynamics have influenced juvenile criminality (Police officers)

\begin{tabular}{|l|c|c|c|}
\hline Statement & N & Mean & Std. Deviation \\
\hline $\begin{array}{l}\text { Government policy including education and awareness policies have } \\
\text { been practiced in different parts of the country on matters concerning } \\
\text { juvenile criminality }\end{array}$ & 62 & 3.56 & .475 \\
\hline $\begin{array}{l}\text { Government supports the society by providing funds to the juvenile } \\
\text { remand homes }\end{array}$ & 62 & 3.10 & .531 \\
\hline $\begin{array}{l}\text { Government partnership with other stakeholders to address the } \\
\text { challenges of juvenile criminality }\end{array}$ & 62 & 3.16 & .628 \\
\hline Overall Mean score & & 3.27 & \\
\hline
\end{tabular}

Means: $0-1.5=\mathbf{S D}, 1.6-3.1=\mathbf{D}, 3.2-4.7=\mathbf{A}$, Above $4.7=\mathbf{S A}$

Key: $\boldsymbol{S D}=$ Strongly Disagree, $\boldsymbol{D}=$ Disagree, $\boldsymbol{N}=$ Neutral, $\boldsymbol{A}=$ Agree, $\boldsymbol{S} \boldsymbol{A}=$ Strongly Agree

Source: Field Data, (2019)

The study results showed that the overall mean score of influence of government dynamics on juvenile criminality in Nakuru sub-county was 3.27. On government policy, the respondents' opinion on the education and awareness policies practiced in different parts of the country on matters concerning juvenile criminality yielded a mean of 3.56 and a SD of 0.475 . Based on the study findings, government does not support the society by proving funds to the juvenile remand homes as supported by a mean of 3.10 and SD of 0.531 . In relation to the government partnership with other stakeholders to address the challenges of juvenile criminality, a mean of 3.16 and SD of 0.628 were obtained.

\subsection{Conclusions and Recommendations}

The study results indicated that there was an important positive association between all the measures of biological dynamics and juvenile criminality in Nakuru sub-county. Dysfunctional family and juvenile criminality in Nakuru sub-county had the highest correlation which was also positive. Biological dynamics was found to influence juvenile criminality and for the success of the juvenile in Kenya it was again concluded that responsiveness of the criminals to the correctional facilities needs was of concern to juvenile criminality because the system should deliver results of an operation to users in a timely and organized manner. The study concluded that there was an influence of biological dynamics on juvenile criminality in Nakuru sub-county, Kenya.

The study outcome revealed that the correlation between all the indicators of social dynamics and juvenile criminality in Nakuru sub-county was statistically significant. Drug abuse and family structure relationship with juvenile criminality in Nakuru sub-county was the strongest and statistically significant. Work independence was on a restrained level and that the out sourced provider's loyalty to the correctional facility was also on an uncertain level. Long term continuity relationship was also on a moderate level. The study concluded that there was an influence of social dynamics on juvenile criminality in Nakuru sub-county, Kenya.

The study findings showed that there was an important positive association between all the measures of economic dynamics and juvenile criminality in Nakuru sub-county. Income inequality and juvenile criminality in Nakuru sub-county had the highest correlation which was also positive. Guardians disagreed that economic dynamics enabled employees learn new approaches to juvenile remand home management. The study established performance evaluation was performed and that the academic provider's commitment to organization development was of a moderate level. Police stated that outsourced police officers only performed satisfactorily. The study concluded that there was an influence of economic dynamics on juvenile criminality in Nakuru sub-county, Kenya.

The study outcome showed a positive correlation between all measures of government dynamics and juvenile criminality in Nakuru sub-county. Government policy and juvenile criminality in Nakuru sub-county had the highest correlation which was statistically significant. There was need for juvenile department to improve on their policies and expected performance in regard to juvenile criminality. Providers were not necessarily committed to organization development. The study concludes that juvenile criminality have also intensified in nature, this has been influenced by the availability of small arms in the country. The study also concludes that there are attempts to dissuade the urban juveniles from engaging in juvenile criminality. These have included initiatives such as the community policing initiatives. Although nit very effective, there are instances where the public has provided information to police officers regarding juvenile criminality in the areas. However, the study also concludes that there is the challenge of trust between the public and the police.

The results revealed that the main institutional dynamics on juvenile criminality are: family education, dysfunctional family, peer influence, drug abuse, urban migration, school drop-out, poverty and unemployment. The study generally conformed to the institutional dynamic theory which mostly dealt with social disorganization 
which stated that most of the juveniles admitted in Nakuru Juvenile Remand Home came from disintegrated families and from families with poor parenting styles and poor families. The study concluded that there was an influence of government dynamics on juvenile criminality in Nakuru sub-county, Kenya.

\subsection{Recommendations for Practice}

- The study found that there was an important positive association between all the measures of biological dynamics and juvenile criminality in Nakuru sub-county and dysfunctional family and juvenile criminality in Nakuru sub-county had the highest correlation which was also positive, hence this study recommends that the government should make efforts in making families functional to reduce juvenile criminality.

- Drug abuse and family structure relationship with juvenile criminality in Nakuru sub-county was found to have the strongest and statistically significant. The study therefore recommends that the County government should make efforts to reduce drug abuse and improve on family structure.

- The study found out that income inequality and juvenile criminality in Nakuru sub-county had the highest correlation which was also positive. The study recommends that the County government should take steps to reduce the gap between the rich and the poor.

- Government policy and juvenile criminality in Nakuru sub-county had the highest correlation which was statistically significant. There is therefore need for juvenile department to improve on their policies and expected performance in regard to juvenile criminality.

\subsection{Recommendations for Further Studies}

The study recommended that the following further areas of study be undertaken;

- The study concentrated on Nakuru sub-county therefore, the generalization of results to other counties needs to be done with caution. The study recommends a similar study to be done in other Counties.

- This study did suggest that further studies can be done on the same sub-County but introducing the elements of moderating variables.

\section{References}

Akers, R. L. (2000).'Criminological Theories: Introduction, Evaluation and Application.(3 ${ }^{\text {rd }}$ edition). Los Angeles, CA: Roxbury Publishing Co.

Amato, P.R. and Keith, "Parental Divorce and the Well-Being of Children: A Meta-Analysis, "Psychological Bulletin 110, No. 1 (1991): 26-46.

Anderson, A. L. and Hughes, L. A. (2009).Exposure to Situations Conducive to Delinquent Behaviors: The Effects of Time Use, Income and Transportation. Journal of Research in Crime and Delinquency 46(1): 5-34.

Apel, R. And Kaukinen, C., "On the Relationship between Family Structure and Antisocial Behavior: Parental Cohabitation and Blending Households," Criminology 46, No. 1 (2008): 35-70.

Cloward, R. and Ohlin, L. (1960).Delinquency and Opportunity. NY: Free Press

Cloward, R. A., and L. E. Ohlin.(2010). Delinquency and opportunity. New York: Free Press.

Cohen, A. K., (1955). Delinquent boys. New York: Free Press.

Collins, J., \& Hussey, R. (2003).Business Research: a practical guide for undergraduate and postgraduate student. ( $2^{\text {nd }}$ edition).Basingstoke. UK: Palgrave Macmillan.

Creswell, J.W. \& (1999).Mixed method research: Introduction and application. In G.J. Cizek (Ed), Handbook of Educational policy. San Diego: Academic Press.

Derzon, J.H. \& Lipsey, M.W. (2000).Juvenile Delinquency. In Elissa, P. Benedek, Peter Ash, and Charles L. Scott (Ed.), Principles and Practice of Child and Adolescent Forensic Mental Health, American Psychiatric Pub, Oct 20, 2009 (pp. 368).

Elizabeth S. S \& Laurence S. (2008).Rethinking Juvenile Justice. Harvard University Press.

Falcetto, A., (2012). Perceptions of Conservation and Ecotourism in the Nakuru sub-county County, Kenya. Masters Theses \& Specialist Projects Paper 1186.http://digitalcommons.wku.edu/theses/1186

Farrington, D. P. (2000). Adolescent violence: Findings and implications from the Cambridge Study. Violent Children and Adolescents: Asking the Question Why. London: Whurr Publishers.

Faris, R. E. L. (1955). Social Disorganization. Ronald Press Company, New York. 300pp.

GOK (2001).Constitution of Kenya "Children and Young persons" Act-Chapter 141 Laws of Kenya".Nairobi: Government Press.

Hirschi, T. (1969).Causes of Delinquency. University of California Press, Berkeley. 300pp.

Hirschi, Travis and Michael Gottfredson (1983).Age and the Explanation of Crime. The American Journal of Sociology, 89 (3), 552-584.

Hirschi, T. (2009). Causes of delinquency. Berkeley: University of California Press.

Loeber, R. \& Stouthamer-Loeber, M. (2006), Family factors as correlates and predictors of juvenile conduct 
problems and delinquency ', in Crime and Justice: An Annual Review of Research, Volume 7, eds. M. Tonry $\&$ N. Morris, The University of Chicago Press, Chicago.

Mak, A.S. (2011), Parental neglect and overprotection as risk factors in delinquency', Australian Journal of Psychology, vol. 46, no. 2, pp. 107-111.

Makokha C.M. (2008) -Factors Influencing Male Delinquents to Commit Capital Offences: A case study of inmates in Kamiti Prison Unpublished University of Nairobi MA Project Paper.

McCord, J., Widom, C.S., and Crowell, N.A., eds. 2001.Juvenile Crime, Juvenile Justice. Panel on Juvenile Crime: Prevention, Treatment, and Control. Washington, DC: National Academy Press.

Mooney, J. and Young, J. (2006).The decline in crime and the rise of anti-social behavior', Probation Journal, $53,4,397-407$.

Muncie, J. (2001) 'The Construction and Deconstruction of Crime', in J. Muncie and E. McLaughlin (eds) The Problem of Crime, 2nd Edition, London: Sage.

Mugenda, O. and Mugenda, A. (I999).Research methods. Quantitative and qualitative approaches. Nairobi: African Center for Technology Studies (ACTS) Press.

Mugenda, O. M. and Mugenda, A. G. (2003), Research Methods, Quantitative and Quantitative Approaches, ACTS Press, Nairobi, Kenya.

Nagin, D.S. \& Smith, D.A. (2010), Participation in and frequency of delinquent behavior: A test for structural differences', Journal of Quantitative Criminology, vol. 6, no.4, pp. 335-356.

Ndichu, E. (2008). Saving the Young Social Worker's Perception of Juvenile Crime Prevention in Sweden. Dissertation for Award of MSc. Social Work Degree at Gothenburg University, Sweden. 78pp.

Newburn, T. (2002) 'Young people, crime and youth justice', in M. Maguire, R. Morgan and R. Reiner (eds) The Oxford Handbook of Criminology, Oxford: Oxford University Press.

Ojo, M.O.D. (2012) . The Journal of International Social Research Volume: 5 Issue: 21pp 465- 482

Omboto J. O., Ondiek G. O., Odhiambo O. \& Ayugi M. E. (2013). Factors influencing youth crime and juvenile delinquency. International Journal of Research In Social Sciences. Vol. 1, No.2

Orodho, A. (2012). Techniques of writing research proposals and reports. Nairobi: Kanezja H P Enterprises.

Orodho, J. (2002). Techniques of Writing Research Proposals and Report. Nairobi. KISE

Prior, D. \& Paris, A. (2005) Preventing Children's Involvement in Crime and Anti-Social Behavior: A literature Review A paper produced for the National Evaluation of the Children's Fund Institute of Applied Social Studies University of Birmingham

Regoli, Robert M. \& Hewitt, John D. (2006).Delinquency in Society. $6^{\text {th }}$ edition.

Sampson, R. \& John L. (2009).Crime in the making: Pathways and turning points through life. Cambridge, Mass.: Harvard University Press.

Sampson, R. (2008). Neighborhood and crime: The structural determinants of personal victimization. Journal of Research in Crime and Delinquency 22:7-40.

Shaw, C. R. \& McKay, H. D. (1969).Juvenile Delinquency and Urban Area (2nd ed.) Chicago: University of Chicago Press.

Siegel, J. Larry. (2002). Juvenile Delinquency with Infotrac: theory, practices and law.

Siegel, Larry J.; Welsh, Brandon (2011).Juvenile Delinquency: The Core (4th ed.). Belmont, CA: Wadsworth/cengage Learning. ISBN 0534519326.

The Daily Nation Newspaper of 26/01/2004.

"The Development of Delinquency. "Institute of Medicine and National Research Council. 2001. Juvenile Crime, Juvenile Justice. Washington, DC: The National Academies Press. doi: 10.17226/9747.

The Sunday Standard Newspaper of 19/10/2010.

The Kenya Police (2010).Annual Crime Report. Nairobi.

UN (1948).The Universal Declaration of Human Rights. UN publication, New York. 11pp.

UN (1989).The Convention on the Rights of the Child. UN publication, New York. 31pp.

UN (2003). Juvenile Delinquency: Delinquent and Criminal Behavior among Young People. World Youth Report. 206pp.

UN (2010). Millennium Development Goals Report. UN publication, New York.80 pp.

UNCHS (1996).The Habitat Agenda, Goals and Principles: Commitments and Global Plan of Action. Proceedings of UNCHS Conference. Istanbul, Turkey, June 1996. 15pp.

UNCHS (1998).Urban Safety and Crime Prevention. Regional Symposium on Urban Poverty in Asia, Proceedings of UNCHS Workshop, Fukuota-Karachi, Pakistan, 27-29 October, 1998. 10pp.

UN-Habitat, (2004).Crimes of the child: Urban criminals start young. UN-Habitat Report. 5pp.

UN-HABITAT, (2007). Nairobi, Crime and Violence: Cities Case Studies. Global Report on Human Settlement.pp1-2.

Vanderschueren, F. (2000).The Prevention of Urban Crime. Paper Presented at the Africities Summit, Windhoek, May 2000. pp. 2-14. 
Visher, C.A. \& Roth, J.A. (2010), Participation in criminal careers ', in Criminal Careers and "Career Criminals, Volume 1, eds. A. Blumstein, J. Cohen, J.A. Roth \& C.A. Visher, National Academy Press, Washington, D.C. Weijters, G. (2008). Youth Delinquency in Dutch Cities and Schools: A multiple approach. Ipskamp Nijmegen Print Partners, Hertogenbosch. 149pp.

Whiteman, L. \& Lowrojee, B. (1997).Juvenile Justice Police Abuse and Detention of Street Children in Kenya Human Right Watch. Children's Rights Project. Human Right Watch, New York: USA.

Yamane, Taro. (1967). Statistics: An Introductory Analysis, $2^{\text {nd }}$ Edition, New York: Harper and Row. 